\title{
Human Security in East Asia: Assembling a Puzzle
}

Yoichi Mine, Oscar A. Gómez, and Ako Muto

\subsection{Human Security and Norm Dynamics}

\subsubsection{An Indelible Agenda}

Human security was advocated by the United Nations Development Programme (UNDP) after the demise of the Cold War (UNDP 1993, $2-3$; 1994, Chap. 2). A quarter of a century has passed since then, and some who were once enthusiastic about this concept no longer discuss it. However, when some lost interest, others took up the idea in other places. ${ }^{1}$ It may thus seem to have faded out from time to time, but in reality, it did not. Where does this persistence come from?

Y. Mine $(\bowtie)$

Graduate School of Global Studies, Doshisha University, Kyoto, Japan e-mail: ymine@mail.doshisha.ac.jp

O. A. Gómez • A. Muto

Research Institute, Japan International Cooperation Agency (JICA), Tokyo, Japan e-mail: oagomez@apu.ac.jp; Muto.Ako@jica.go.jp

(C) The Author(s) 2019

Y. Mine et al. (eds.), Human Security Norms in East Asia, Security, Development and Human Rights in East Asia, https://doi.org/10.1007/978-3-319-97247-3_1 
Human security is an international norm concerned with global public interest, or a concept that aims to be an international norm such as human rights, the Sustainable Development Goals (SDGs), and corporate social responsibility (CSR). In general terms, norms denote codes of desirable (or undesirable) behaviors shared in a specific community. One of the strongest norms common in human society is that "homicide is evil." Even when the death penalty and war are allowed, they are considered exceptions to this norm. Written norms become statutes and formal regulations, while social consciousness supporting specific codes of conduct can also be called norms. ${ }^{2}$ Normative sciences not only describe facts but also inquire into "how the object ought to be," covering logic, ethics, and aesthetics. The study of norms can be part of such an intellectual exercise: we describe and evaluate what people consider to be appropriate behaviors, nationally and internationally.

Let us try to answer the above question. Why does human security not fade out? It is because the international community needs this concept. Though not explicitly using this term, the UN can be thought of as being originally organized to realize human security beyond international security. The originality of human security as an international norm lies in its attempt to shift the referent object of security from "states" to "individuals" and to urge various actors to conduct themselves accordingly. The two world wars in the twentieth century claimed large numbers of human lives and stripped as many of their dignity and property in the all-out wars between nation states. In order not to repeat such calamities, the UN conferred on its Security Council the authority to limit the sovereignty of states threatening international peace and security and to impose military sanctions under international law. In the UN, state sovereignty is not necessarily an inviolable sanctuary, even though "non-interference" remains a major norm in international society.

It is often assumed that Hobbes' "realism" and Kant's "idealism" are poles apart. However, if the nation-state is invented to overcome the havoc caused by the war of every man against every man (Hobbes 1996 [originally 1651]), and a world federation is shaped to avoid the devastation caused by the war of every state against every other state (Kant 1977 [originally 1795]), these two world views are conterminous in a single spectrum. In this light, the ultimate objective of both nation states and international organizations is to realize the security of individuals by ensuring freedom for all people. Therefore, it is of pressing importance to evaluate government functions on the extent to which they serve this 
objective. Although we cannot deny the crucial roles of nation states and national governments, the strong nation states are those that effectively serve the security of individuals living in their territories, not those that demand citizens' sacrifice for state security too easily. In a nutshell, the normative message of human security boils down to a powerful proposition that the ultimate objective of governance at all levels is to provide security (or ensure freedoms) for every individual.

\subsubsection{Human Security as a "Norm-Complex"}

The core message of human security is thus very simple, but many other intentions and meanings have been subsumed in this concept along the way. If the objective is the security of individual persons, we must be able to characterize the core constitutive elements of such a secure state, as well as the principal means to achieve that goal, which can be described as norms themselves. Human security is being formed as a "norm-complex" in which different existing norms are combined and nested under the umbrella of human security (Kurusu 2005). ${ }^{3}$ This hybrid nature of human security is observable in the consensus-based resolution on the definition of human security adopted by the United Nations General Assembly (UNGA) in September 2012. ${ }^{4}$

That resolution stipulates that human security is "an approach to assist Member States in identifying and addressing widespread and cross-cutting challenges to survival, livelihood and dignity of their people." According to the resolution, a common understanding on the notion of human security includes: "(a) The right of people to live in freedom and dignity, free from poverty and despair. All individuals, especially vulnerable people, are entitled to freedom from fear and freedom from want, with an equal opportunity to enjoy all their rights and fully develop their human potential." The resolution then enumerates certain qualifications of the concept: "(b) Human security calls for people-centred, comprehensive, context-specific and preventionoriented responses that strengthen the protection and empowerment of all people and all communities," "(c) Human security recognizes the interlinkages between peace, development and human rights, and equally considers civil, political, economic, social and cultural rights," "(d) The notion of human security is distinct from the responsibility to protect and its implementation," and "(e) Human security does not entail the threat or the use of force or coercive measures" and "does not replace State security." Human security thus makes much of "national ownership," local contexts and bottom-up initiatives, and pays respect to all generations of human rights. 
Based on the characterization of human security in past documents, including this UNGA resolution as well as the Commission on Human Security (2003) and UNDP (1993, 1994), we defined the practice of human security for the present research as follows: to ensure three freedoms (freedom from fear, freedom from want, and freedom to live in dignity) for individuals and communities vulnerable to large-scale and cross-border threats, by combining protection from above and empowerment from below. Although this definition may still feel too complicated, with careful attention, one finds that the concept has been made dynamic by incorporating new elements into a set of established norms. Let us discuss three points.

First, while taking the concept of "freedoms from fear and want" as a given, human security brought in the third element, "dignity." Realizing a world free from "fear and want" is the ideal of the Universal Declaration of Human Rights, and these two freedoms can be represented by civil liberties and socio-economic rights. They are embedded in the national constitutions of many nations as well as in international human rights law. On the other hand, dignity corresponds to a moral attitude when aiming at the realization of these freedoms: to express respect for humanity, recognizing that every human being has intrinsic worth (Rosen 2012). It is impossible to think of the human rights of the dead, even though we do think of the dignity of the dead. This is because dignity is a relational concept, and practical methods to respect the irreplaceability of others depend on local cultural contexts. ${ }^{5}$

Second, while human security does not deny the importance of protection, it incorporates the element of "empowering" people from below as a complement to protecting them from above. Empowerment is a process that enables people to become the masters of their own lives and may require the redistribution of power and resources between the powerful and the powerless. In the context of social development, Friedman (1992) developed a theory of empowerment focusing on community development and livelihood support. Women's empowerment has been incorporated into both the Millennium Development Goals (MDGs) and, more recently, the SDGs. Self-evaluation tools for empowerment processes have also been developed (Fetterman et al. 2015). If practitioners of human security want to translate empowerment into practice, it is important for them to unambiguously respect the agency of local people while avoiding their protracted dependence on assistance wherever possible. By reinforcing the power not only of individuals but also of communities and local governments, the excessive power of national governments can also be 
effectively checked. In human security, it is important to lower the level of the focus of empowerment from the national to the subnational and down to the community level.

Thus, in the human security discourse, by adding the concepts of dignity and empowerment, the elements of culture and agency have been grafted onto existing norms of human rights and humanitarian intervention. This deserves more attention as a new value that has been added to the human security idea. In East Asia, where social hierarchy is relatively strongly rooted, the concept of dignity based on the premise that individuals are embedded in society can be accepted more easily than the concept of empowerment that might "disturb" public order. However, as a counterbalance to public authorities' sometimes excessively paternalistic protection, the emphasis on empowerment is undeniably of great significance in this region. ${ }^{6}$

The third source of power that can dynamize human security is the awareness that human society is in danger. Mahbub ul Haq, a Pakistani economist and the first advocate of human security in the UN, wrote: "A powerful, revolutionary idea, the emerging concept of human security forces a new morality on all of us through a perception of common threats to our very survival (...) While great religions often move the human spirit through the sublimeness of their messages, they also carry in their messages the fear of eventual punishment. Much human change comes from a fear for human survival (Haq 1995, 116)." We cannot fully control the forces of nature or the fate of humanity. In envisioning a sustainable future for human beings and nature, the human security idea is expected to contribute to the realization of the SDGs through its emphasis on serious and pervasive threats (downside risks) and people's vulnerability to these.

Human security as defined in the UNGA resolution makes much of national ownership in organizing human security action. The implication of this approach will be discussed further in the rest of this volume.

\subsubsection{Norm Dynamics}

Modern international norms involving many and diverse stakeholders tend to be complex, which relates to the ways a norm is established. There is a normative process of norm-making: in other words, a desirable process that is the standard way of setting a new norm. Wise people may gather to put bonum commune of humankind into statutory forms and diffuse this downward. However, the actual processes of norm creation and diffusion are a 
little different. For an idea to be established as a norm, it must be internalized in the minds of the members of society irrespective of whether it is legally enforced or not. For this purpose, it is desirable for as many parties as possible at the center and at the periphery to actively participate in the process of norm-making instead of passively waiting for the advent of a new norm. In this process, both universal and local values tend to slot into a new norm, thereby making it hybrid, composite, or complex.

International norms are said to have life cycles. At the beginning, "norm entrepreneurs" propose a new norm, which is accepted by several states (the norm emergence stage). Then, after a certain "tipping point," the norm diffuses quickly and prevails throughout international society (the norm cascade stage). Finally, the norm is internalized in every country and becomes "taken for granted" (the internalization stage) (Finnemore and Sikkink 1998). However, as clarified by Amitav Acharya in the case of the security regime in Southeast Asia, foreign norms may be opposed, modified, or displaced by existing local norms in local space. Norms are not simply accepted or rejected but are also localized (Acharya 2004; 2009). Conversely, new norms that are (re)created by local actors in the periphery may eventually reach the core nations and/or challenge global powers (Acharya 2011; Towns 2012). As indicated by the concept of bricolage in cultural anthropology (Lévi-Strauss 1962), people living in communities bring together various indigenous and foreign materials to ingeniously create a new modality of life. Proposed norms are to diffuse or fade out while being transformed vertically from the UN headquarters to a small village, and horizontally across diverse world regions and nations.

The process of initiation, diffusion, and regeneration of a norm is called "norm dynamics." As described above, the concept of human security was first advocated by a group of norm entrepreneurs at the UNDP, consisting of Mahbub ul Haq and others. After that, several countries including Canada reinterpreted the human security concept, and this gave rise to an offshoot norm called responsibility to protect (R2P), which defined the conditions for international society to intervene into a sovereign state with military and/or non-military measures to directly protect citizens from the horror of "genocide, war crimes, ethnic cleansing and crimes against humanity." 8 On the other hand, countries including Japan, Thailand, and the Philippines understood the nature of threats in broader and more comprehensive ways and tried to redefine human security to avoid confrontation between state sovereignty and humanitarian imperatives by emphasizing prevention and sensitivity to local contexts. 
It should be noted that the comprehensive human security initiative of the latter group, maintaining the universality of UN-based messages, has passed through the process of localization in Asia. A radical change of international norms is often triggered by a dispute or a grave event (Sandholtz and Stiles 2009). The Prime Minister of Japan, Keizo Obuchi, officially advocated human security for the first time in Singapore in 1998 after the Asian financial crisis (he was Foreign Minister at the time) (Kurusu 2011). The Commission on Human Security, which released the final report on the comprehensive human security approach in 2003, was co-chaired by the former United Nations High Commissioner for Refugees (UNHCR) Sadako Ogata and the Nobel Prize-winning economist Amartya Sen, a combination of East Asian and South Asian universal figures (CHS 2003). Pitsuwan and Caballero-Anthony (2014) relate the effects of the financial crises, as well as the multiple humanitarian crises, that have made evident the significance of human security as a "compelling normative framework." Still, they argue "that as far as institutionalizing human security in its security practices, ... ASEAN still has a long way to go," particularly because of gaps in economic security, protection from disasters and of minorities and migrants, among others.

In the rest of this introductory chapter, we discuss how the concept of human security has been received in East Asia in terms of the perspective of norm dynamics. What do Asian countries accept, reject, or remodel of the idea of human security born in the UN? In this book, the so-called ASEAN Plus Three countries (the member states of the Association of Southeast Asian Nations (ASEAN) plus China, Japan, and South Korea) is defined as East Asia. In this region that has experienced "miraculous" growth (World Bank 1993), the nexus between economic development and human insecurities is prominent. ${ }^{9}$

\subsection{The Localization of Human Security}

\subsubsection{Diffusion in Asian Settings}

Japan is not the only country that has accepted the human security norm in Asia. The late Surin Pitsuwan, a member of the Commission on Human Security and Distinguished Fellow of the JICA Research Institute, persevered in his effort to diffuse the concept of human security in Southeast Asia, serving as the Minister of Foreign Affairs of Thailand and then as Secretary General of ASEAN. As discussed in Chap. 11, in 2002 the gov- 
ernment of Thailand set up the first government ministry in the world bearing the name of human security: The Ministry of Social Development and Human Security. In Thailand, knowledge on human security had been widely diffused among academic researchers, but the practice of human security canalized by the establishment of this ministry came to focus on the social welfare of the vulnerable: persons with disabilities, the elderly, children, women, and ethnic minorities.

The Philippines also paid attention to human security as soon as the 1994 UNDP report was released, and multiple efforts of localization can be enumerated, including the design of a "human security index." There have been attempts of co-option as well. An antiterrorism law called the "Human Security Act" was enacted in 2007, inviting criticism from Filipino civil society (Chap. 8). Application of the concept of human security in Thailand and the Philippines headed in the opposite directions of benign welfare and hardline public order.

The Chinese government does not often mention human security, but Chap. 3 argues that China articulates a vision similar to this concept and practices it without saying so. That is partly because China, a permanent member of the UN Security Council, is expected to promote international norms embraced by the UN system. The acceptance of human security by way of participation in multilateral stages is applicable to South Korea as well. In 2010, South Korea became a member of the Organisation for Economic Co-operation and Development-Development Assistance Committee (OECD-DAC). In addition, Ban Ki-moon promoted human security in his capacity as UN Secretary-General. Also, the government of South Korea has occasionally referred to the importance of human security in addresses by its President and Foreign Minister (Chap. 10).

Thus, in East Asia, several countries have accepted the concept of human security to varying degrees under government initiatives. In the meantime, local scholars have also accumulated academic inquiries. In addition to two major single-authored books (Howe 2013; Nishikawa 2010), a train of edited volumes on human security in the East Asian contexts has been published (Kassim 2011; Peou 2009; Teh 2012; Tow et al. 2000, 2013; Umegaki et al. 2009). Moreover, with relatively limited circulation, the proceedings, commentaries, and policy recommendations based on international conferences held in Bangkok, Seoul, Jakarta, and so on, have been published one after another (Banpasirichote et al. 2012; Hernandez and Kraft 2012; Thabchumpon 2012; UNESCO 2004, 2007; Wun'gaeo 2004). These publications have shared a certain feature: authors based in East Asia transmit messages mainly to readers within the region. 
These earlier studies, especially most of the edited volumes, discuss how concrete issues can be interpreted using the concept of human security and how those issues can be addressed on the ground. However, there is little research that digs into the processes by which individual countries in the East Asian region have accepted the human security norm in their own ways. The country-by-country analyses in this book are expected to fill this gap.

\subsubsection{The Launch of Collaborative Work}

In 2003, when the final report of the Commission on Human Security was published, Sadako Ogata returned to Japan to take the helm of the Japan International Cooperation Agency (JICA). Under her presidency, the human security idea became embedded in the spirit of the agency. When a part of the Japan Bank for International Cooperation (JBIC) and JICA were integrated to set up the new JICA in 2008, the JICA Research Institute was established and launched several international research projects related to human security.

Then, in 2013, a research project to directly investigate the norm dynamics of human security in East Asia was set up. Based on a common questionnaire, researchers from 11 East Asian countries were to work on interview surveys and document research to elucidate the present status of human security in each country (see Fig. 1.1). The researchers participating in the project - the authors of the chapters in this book-are a combination of senior and young scholars specializing in international relations, political science, development studies and other disciplines and working for universities and think tanks in various parts of the region.

The researchers agreed to ask questions about the following three topics in the interviews: first, local perceptions of threats (the ranking of human security issues that are considered important in each country and in the East Asian region); second, the ways of (selective) acceptance of the concept of human security (the understanding of freedoms from fear, from want and to live in dignity, the strategy for combining protection and empowerment, and the understanding of preparedness for calamities, and so on); and third, the question of national sovereignty (whether to allow foreign actors to operate within the country in case of natural disasters and violent conflict, as well as whether to take action in territories of other countries in such a case). At the same time, respondents were allowed to change the combination of interview questions to adapt to their countries' unique circumstances. In addition, it was agreed that the researchers would welcome responses criticizing human security. 


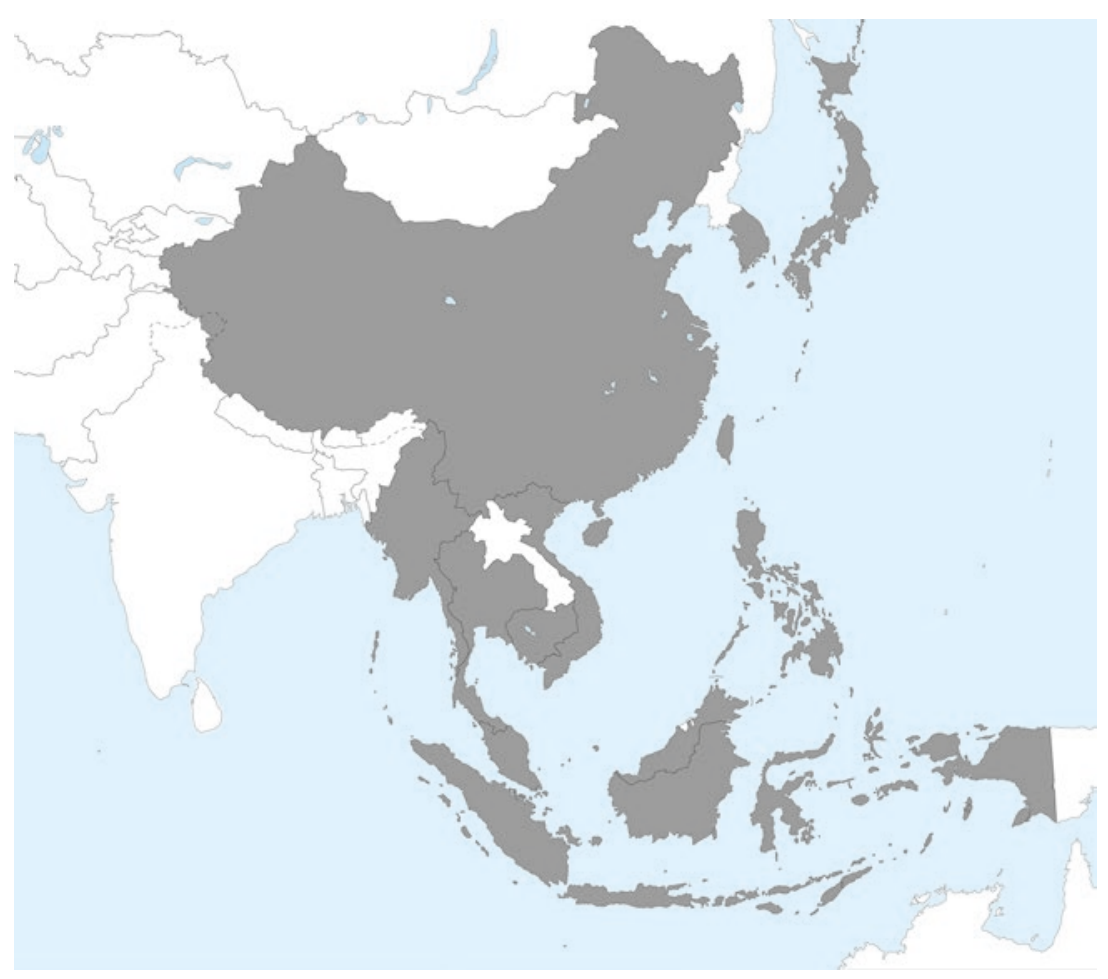

Fig. 1.1 Countries where case studies were conducted (Japan, China, South Korea, and several ASEAN countries: Indonesia, Cambodia, Singapore, Thailand, the Philippines, Vietnam, Malaysia, and Myanmar)

The interviewees included government officials, lawmakers, researchers at universities and think tanks, nongovernmental organization (NGO) activists, religious leaders, journalists, business persons, and international organization staff. Though they were not necessarily statistically representative, in-depth interviews were conducted (some of the survey activities included anthropological interviews with villagers in the countryside and focus group discussions). The interviews reached more than a hundred, and two workshops for chapter authors were organized in Tokyo and Manila. In the next section, we put together the research outcomes in the light of norm dynamics, including the localization processes. 


\subsection{The Current Status of Human Security In EAST Asia}

\subsubsection{Perceptions of Threats}

First, let us think about what threats to human security we face. Classifying the sources of threats to human security into those derived from the physical system (the earth), from the living system (animals and plants), and from the social system (human beings), Akihiko Tanaka called for a clearer understanding of the mechanism in which these threats bring about human insecurities. To that end, close collaboration between different academic disciplines including the natural sciences and engineering, the biological and ecological sciences, and the social sciences and the humanities is required (Tanaka 2015).

In our surveys of the 11 East Asian countries, local experts were asked to enumerate the threats to human security. Though priority ranking varies from country to country, an integrated list of threats arranged according to the above three systems can be as follows: climate change, typhoons/ cyclones, floods, volcano eruptions, earthquakes, tsunami, infectious diseases such as Severe Acute Respiratory Syndrome (SARS), avian influenza and HIV/AIDS, food crises, lack of basic health and education, environmental pollution, urbanization, extreme poverty, unemployment, migration, human trafficking, violent conflicts, interstate military conflicts, religious intolerance, organized crime, oppression from the government, and so forth.

Meanwhile, the UNDP's Human Development Report 1994 listed seven main categories of human security: economic, food, health, environmental, personal, community, and political security (UNDP 1994, Chap. 2). In the case studies of Cambodia (Chap. 2), Thailand (Chap. 11), the Philippines (Chap. 8), and Vietnam (Chap. 12), human security challenges are classified in line with these seven categories. These areas correspond not only to the divisions of the UN Specialized Agencies but also to government ministries, so that the classification could be accepted as familiar and practical.

Such a diversity of threats largely overlaps with the so-called nontraditional security (NTS) issues. While military threats from foreign states are considered "traditional," many threats that simultaneously affect multiple countries are of a non-military nature and fall into the category of "non-traditional" threats. As pointed out in the cases of China (Chap. 3), 
Indonesia (Chap. 4), Malaysia (Chap. 6), the Philippines (Chap. 8), South Korea (Chap. 10), and Vietnam (Chap. 12), there is growing interest in NTS among policymakers and researchers in China, South Korea and in the ASEAN countries, which seems to have contributed to the acceptance of human security in the region (Caballero-Anthony et al. 2006; CaballeroAnthony and Cook 2013; Li 2010). However, there is substantial difference between the NTS and the human security approach: while the actors that address such diverse threats still concentrate on the national governments in the former, more emphasis is placed on peer collaboration between states and other actors in the latter. The role of national armies in coping with human security challenges should be limited. Chapter 4 presents the opinion of an Indonesian military officer who argued that the term "security" should not be used until the poverty level or the impact of a disaster exceeded a certain threshold and becomes a real threat to the survival of all citizens. If every threat was considered a security challenge, the military would be overwhelmed by the resulting deluge of duties.

Human security is regarded as a principle of official development assistance (ODA) policies in Japan, and to a lesser extent, in South Korea. As described in Chap. 5, in Japan, the idea to combine efforts toward development and peacebuilding has gradually taken root under this framework. As an added value of human security, Japanese interviewees emphasized the importance of a "comprehensive approach" in which diverse actors (including NGOs and private firms) cooperate, as well as the significance of working among grassroots people and paying more attention to real needs in the field. Meanwhile, most experts pointed out that human security challenges lie on the domestic front, too. People who were familiar with the concept of human security interpreted the Great East Japan Earthquake and the resultant Fukushima disaster as a typical human security issue. In addition, the aging population and a possible collapse of social security in the future can also be serious domestic human insecurity issues.

In terms of domestic human security challenges, the case of Singapore as presented in Chap. 9 is also revealing. While Singapore has achieved a high degree of human security as a developed country in Southeast Asia, this small city-state is also going through acute human insecurities such as growing inequalities, increasing psychological stresses on citizens, the survival race between small enterprises, and discrimination against migrants and minorities. Here, social media cuts two ways by spreading messages virally: it can mobilize good will but may also deeply wound people. In Singapore, with strong administrative control from above, empowerment 
is supposed to be of great significance. Besides, Singapore assists neighboring countries in the form of philanthropy, even though this is not officially classified as ODA. It is pointed out that the Philippines has also provided humanitarian assistance while receiving assistance itself (Chap. 8). In the Great East Japan Earthquake, Japan, a major provider of ODA, received goodwill support from many countries including recipients of Japan's assistance (Chap. 5). It is noteworthy that the line separating providers from recipients of ODA is blurred in the case of humanitarian crises.

A country that has faced a series of exceptionally acute threats to human security is Cambodia (Chap. 2). This country is considered "a showcase of human insecurities" that started with the genocide under the Pol Pot regime (it is said that around 2 million people were killed in a country with a population of 8 million). The interviewees enumerated contemporary sources of threats in Cambodia such as the government, natural disasters, diseases, political insecurity, and land issues. Some respondents pinpointed the problem of the "government approach, relying on the heavy presence of security forces and legal means to threaten and detain people." It is widely perceived that Cambodian society has been destabilized and that human security has been threatened despite (or due to) recent economic growth.

One of the topical concerns in East Asia that has wider political implications is the North Korean issue (Chap. 10). An emergency on the Korean Peninsula could bring about an exodus of refugees and other situations, which may potentially give rise to grave human insecurities both regionally and globally. The risk of military conflict over maritime interests could also be a threat to human security, as voiced by several countries. The necessity to address cross-border issues such as human trafficking, air pollution, infectious diseases, food security, and cybersecurity was also pointed out by many interviewees.

\subsubsection{The Parts and the Whole}

How far has the concept of human security permeated East Asian countries so that stakeholders can jointly address the multiple threats described thus far? As pointed out in those chapters that discuss the experiences in the Philippines (Chap. 8), Malaysia (Chap. 6), and Thailand (Chap. 11), East Asian experts did not fully understand the difference between human security and human rights or human development, while activists in civil society tended to use the discourse of human rights more often than that 
of human security. However, even though the human security norm has not prevailed in East Asia, the concept has been accepted at least partially, as argued in several of the case study chapters.

The survey carried out in Vietnam (Chap. 12) broke down human security into the seven security categories of the UNDP and found that all these elements were inscribed into the Vietnamese Constitution and other laws. In addition, even when interviewees were not familiar with the concept of human security, they "were able to quickly connect the abstract concepts of 'freedom from fear', 'freedom from want', and 'freedom to live in dignity' to specific examples in their lives." Human security in Vietnam "can be said to be a jigsaw puzzle, in which the pieces are identified, but have not been put together." The surveys in Indonesia (Chap. 4) and South Korea (Chap. 10) also found, by examining official documents, that the elements of human security defined in this chapter, such as the three freedoms, protection, and empowerment, were all written into these documents to varying degrees (the former in domestic policies and the latter in ODA policies). In addition, people who were interviewed in Cambodia pointed out that the three freedoms were closely linked to each other in substance (Chap. 2).

What is the most important element among the components that make up human security? The study of Japan (Chap. 5) presented the expert opinion that the third "freedom to live in dignity" could be a real added value of the human security approach, indicating that "dignity is an idea of waiting and caring." The survey in the Philippines also mentioned that the concept of dignity had potential to lead human security to a higher dimension and emphasized the importance of local contexts. Moreover, people in Cambodia said that having dignity is associated with "having a moral character; with notions of respect, pride, and having value and independence; and of helping others and having an honest character." A rural resident made a candid remark: "Dignity is most important because it is about no discrimination, having rights to do what we want, not being looked down upon by wealthy people."

While the expectation of state protection was found in many interview results, empowerment was mostly referred to in general terms. However, protection and empowerment make an effective pair in reality. Empowerment leads to a series of concepts that value people's agency, such as ownership, self-help support, resilience, and capacity development in the practice of development cooperation, while the same concept is expected to promote collaboration between governments and civil society 
in domestic policies. Given that the Asian approach to human security tends to give relative weight to the role of states as discussed below, the counterbalance of empowerment is needed all the more in this region.

\subsubsection{Human Security and State Security}

In many countries, we also asked the interviewees whether foreign support should be accepted in case their own country suffers an uncontrollable crisis due to a natural disaster or violent conflict (and whether their country should support neighboring countries in case the latter suffers the same situations). The common pattern of responses to these hypothetical situations was that foreign support was undesirable during political unrest but welcome when a natural disaster occurs. It was also preferred that the support should be provided in multilateral rather than unilateral frameworks, as mentioned in the studies on Malaysia (Chap. 6), the Philippines (Chap. 8), and Vietnam (Chap. 12). These reactions illustrate that East Asians tend to think that state security could be compromised in favor of humanitarian concerns in certain emergency situations, especially in case of natural disasters. It should be remembered that Sadako Ogata stressed that human security and state security complement one another (Ogata 2003). ${ }^{10}$

As to the role of states in realizing human security, both a loose consensus and a subtle disagreement could be found among East Asian countries. The case study of China argues as follows (Chap. 3). On the one hand, we can establish the causal connection that state security contributes to human security. The idea that people should not be easily sacrificed for national objectives is absolutely correct because human beings are not means but ends in themselves. On the other hand, national security and personal security can be compatible. The perception that states are a "necessary evil" is not a Chinese but a Western idea. East Asians naturally expect a great deal from their governments: people expect the governments to protect them just like parents protect their children. This represents a view of states as benevolent and "paternalistic." The relationship in which a stable state guarantees people's security is also expressed in the case study of Vietnam (Chap. 12).

On the "right" of this view of states, there is another understanding that human security is part of state security, that is, state security subordinates human security, not vice versa. In this research project, such a view was expressed by government officers from Indonesia (Chap. 4) and Malaysia (Chap. 6). From the government side, however, some added that 
the role of the military in human security should be strictly limited. Indonesian interviewees opined that military operations should be firmly placed under civilian control, even though the military effectively responded to the earthquake and tsunami in 2004. This is because they consider that the military is essentially not trained to respond to nonmilitary threats, and it is often better to entrust the duty of maintaining public order to police forces in disaster situations.

On the "left" side, there are countries with impressive traditions of civil society activism such as the Philippines (Chap. 8) and Thailand (Chap. 11), which have strongly influenced the trajectories of acceptance of human security. In the case studies of Malaysia (Chap. 6) and Singapore (Chap. 9), dynamic and strained relationships between the government and civil society are vividly depicted. The chapter on Malaysia places expectations in consolidating human security through empowerment of local governments, more active dialogues between the government and civil society, and regional cooperation through the networks of ASEAN and NGOs, against the backdrop of the government repression of free speech, religious intolerance, and the surge of Rohingya refugees.

When severe threats to human security are actualized, the relationship between state sovereignty and human security may become extremely tense. As described in Chap. 7, when Cyclone Nargis hit Myanmar in 2008, the military government refused to accept foreign aid, even while lowland residents were caught in the flooding. It is said that the dead and missing persons numbered nearly 140,000 . Though Western countries such as France threatened to make a R2P-type humanitarian intervention, the government of Myanmar rejected such operations and instead decided to accept coordinated assistance from organizations such as ASEAN and the UN. This multilateral collaboration has become a model for humanitarian operations in East Asia.

The case study of Japan (Chap. 5) warns that the concept of human security could be "politicized" in the contexts of domestic debates on security and securitization. In contrast, the study of Thailand (Chap. 11) voices concern that human security is now too "depoliticized," arguing that the concept has been reduced to the practice of social welfare and is now rarely discussed in Thai diplomatic contexts. However, behind the activities of the Ministry of Social Development and Human Security seeking to improve the well-being of the socially vulnerable seems to lie the Buddhist concept of mercy as well as an attempt to integrate human security with the concept of sufficiency economy advocated by King Rama IX. These dynamics of 
politicization, depoliticization, and local reinterpretation are interesting in terms of the "norm localization" discussed in this chapter.

Keeping in mind the urgent problems including land grabbing and King Sihanouk's political legacy in Cambodia, Chap. 2 emphasizes the importance of "cooperative leadership" based on the spirit of tolerance and compromise. The key to ensuring human security in Cambodia is to realize voluntary collaboration among opposing political parties, between the government and civil society, and between the central and local governments, and to make the government listen to the voice of the people.

Different countries have different perceptions as to which state and non-state actors should be valued as against others. However, we can safely say that there is a shared understanding in the region that diverse actors, including national governments, should coordinate each other's activities to secure freedoms and development for individual persons in the face of serious and pervasive threats.

\subsection{Conclusions}

Just as a world where autonomous villages cease to make decisions on their own affairs is hard to imagine, it is unlikely that the governments of nation states will cease to make their own decisions. National governments are important because most of them have strong powers and the authority to ensure security for individuals by utilizing well-developed institutions, resources, and national cohesion. However, overly powerful state security mechanisms require an antidote, which can be the human security norm. As history illustrates, when pluralist thinking that endorses critical roles played by non-state actors is denied, the world as well as national politics go awry. ${ }^{11}$

The purpose of the association of world peoples is not only to promote the security of nations but also to ultimately promote the security of all human beings. In this sense, the Security Council of the UN could be renamed a Human Security Council. In the practice of human security, neither "Western individualism" nor "Oriental despotism" is required in their pure forms; it seems that Asian versions of human security have begun walking along the middle road between the two. In East Asian nations, perceptions of diverse threats as sources of insecurities largely overlap, and therefore the conditions for collective action to address common threats also seem to be maturing. 
Even though the term human security is not officially used very often, in this research it was found that the constituent elements of human security, namely, the three freedoms as well as protection and empowerment, have been accepted more or less in all parts of East Asia. If regional spaces for dialogues are provided, the human security idea may diffuse in the short term like a cascade. An international network of experts sharing the value of a specific norm and assuming key roles in its diffusion as well as policy coordination is called an epistemic community (Haas 1992). In the process of this research, we witnessed the emergence of a bridged community with a shared interest in human security in East Asia. The process of this research endeavor itself might be part of the formation of such a community.

Lastly, we would like to pay notice to the fact that the outcomes of this research reflect not only East Asia's potential unity but also its actual diversity. Once we zoom in to the regional space of East Asia, we can see a kaleidoscopic diversity of human security stakeholders and their values. This is the reason why this book is entitled Human Security Norms rather than The Human Security Norm. The latter is only in the making: there remain forces that resist the idea of human security, while East Asian nations are developing their own human security norms with different interpretations and preferences.

The country-by-country analyses in subsequent chapters are based on independent research, which seems to have succeeded in shedding light upon the diversity of the history, society, and political economy of the region. The chapters are arranged in the alphabetical order of countries, so readers can start with any chapter while referring to the comparative analysis in Chap. 13. We return to the issue of East Asia's diversity in Chap. 14, in which we will suggest a direction to proceed with the practice of human security in this region.

\section{Notes}

1. Martin and Owen (2014) present a stock-taking collection of reflections on the concept and its application. Bourbeau (2015) captures the multidisciplinary nature of the study of security, including human security.

2. In international relations, norms are defined as "shared expectations about appropriate behavior held by a community of actors" (Finnemore 1996, 22 ) or "collective expectations for the proper behavior of actors with a 
given identity" (Katzenstein 1996, 5). Criticizing the proposition that human rights make sense only when they are legally guaranteed, Amartya Sen argues that strong moral imperatives of what to do and not to do make up human rights. These imperatives may call for legislation, but legal provision is not a prerequisite for human rights (Sen 2009, 355-87). As in the case of human rights, a set of moral judgments often precedes the formalization of norms.

3. See also the discussions of "composite norms" in Betts and Orchard (2014).

4. United Nations General Assembly, Follow-up to paragraph 143 on human security of the 2005 World Summit Outcome, 6 September 2012, A/66 L.55/Rev.1. See also the website of the UN Trust Fund for Human Security: http://www.un.org/humansecurity/

5. For this reason, when translating the notion of dignity into practice, it is essential to gain insights into non-Western value systems, as demonstrated by Debes (2017) and Düwell et al. (2014). The concept of dignity was explicitly introduced to the human security discourse in the Commission on Human Security (2003) as one of the triad of "survival, livelihood and dignity."

6. Dignity has long been debated in bioethics and philosophy of law, but it has not yet permeated the study of development and peace building. However, Annan (2005) has introduced "freedom to live in dignity" into the agenda of the UN reform, and Tadjbakhsh and Chenoy (2007) have attempted to incorporate dignity fully into the human security perspective. On the other hand, while the concept of empowerment is widely diffused in social movements in the Americas and South Asia, East Asians still seem to be hesitant to fully discuss its implications.

7. After a norm is established by idealistic "norm entrepreneurs," a different group of pragmatic actors called "message entrepreneurs" start negotiating a consensus to give a concrete shape to the norm (Fukuda-Parr and Hulme 2011), as the drafters of the 2012 UNGA resolution did in the UN.

8. United Nations General Assembly, 2005 World Summit Outcome, 15 September 2005, A/60/L.1, paras. 138-9.

9. Human development and human security correspond to the upside and the downside of economic growth, and to the dual policy challenges of "growth with equity" and "downturn with security" (Sen 2003). See also Chap. 13.

10. For the role of states to promote human security, see Bae and Maruyama (2015), a collaborative work by American and Japanese scholars of human security.

11. The criticism of political pluralism by Carl Schmitt (Schmitt 1976 [originally 1932$]$ ) was typically a product of the time of state nationalism on the eve of the Second World War. 


\section{REFERENCES}

Acharya, Amitav. 2004. How Ideas Spread: Whose Norms Matter? Norm Localization and Institutional Change in Asian Regionalism. International Organization 58 (2): 239-275.

- 2009. Whose Ideas Matter? Agency and Power in Asian Regionalism. Ithaca: Cornell University Press.

- 2011. Norm Subsidiarity and Regional Orders: Sovereignty, Regionalism, and Rule-Making in the Third World. International Studies Quarterly 55: 95-123.

Annan, Kofi A. 2005. In Larger Freedom: Towards Development, Security and Human Rights for All: Report of the Secretary-General. New York: United Nations Department of Public Information.

Bae, Sangmin, and Makoto Maruyama, eds. 2015. Human Security, Changing States and Global Responses: Institutions and Practices. Abingdon, Oxon: Routledge.

Banpasirichote, Chantana, Philippe Doneys, Mike Hayes, and Chandan Sengupta, eds. 2012. Mainstreaming Human Security: Asian Perspectives. Bangkok: Chula Global Network and International Development Studies Program, Chulalongkorn University.

Betts, Alexander, and Phil Orchard, eds. 2014. Implementation and World Politics: How International Norms Change Practice. Oxford: Oxford University Press.

Bourbeau, Philippe, ed. 2015. Security: Dialogue across Disciplines. Cambridge: Cambridge University Press.

Caballero-Anthony, Mely, and Alistair D.B. Cook, eds. 2013. Non-Traditional Security in Asia: Issues, Challenges and Framework for Action. Singapore: Institute of Southeast Asian Studies.

Caballero-Anthony, Mely, Ralf Emmers, and Amitav Acharya, eds. 2006. NonTraditional Security in Asia: Dilemmas in Securitization. Aldershot: Ashgate.

CHS (Commission on Human Security). 2003. Human Security Now. New York: Commission on Human Security.

Debes, Remy, ed. 2017. Dignity: A History. Oxford: Oxford University Press.

Düwell, Marcus, Jens Braarvig, Roger Brownsword, and Dietmar Mieth, eds. 2014. The Cambridge Handbook of Human Dignity: Interdisciplinary Perspectives. Cambridge: Cambridge University Press.

Fetterman, David M., Shakeh J. Kaftarian, and Abraham Wandersman, eds. 2015. Empowerment Evaluation: Knowledge and Tools for Self-Assessment, Evaluation Capacity Building, and Accountability. 2nd ed. Thousand Oaks: Sage.

Finnemore, Martha. 1996. National Interests in International Society. Ithaca: Cornell University Press.

Finnemore, Martha, and Kathryn Sikkink. 1998. International Norm Dynamics and Political Change. International Organization 52 (4): 887-917.

Friedmann, John. 1992. Empowerment: The Politics of Alternative Development. Cambridge, MA: Blackwell. 
Fukuda-Parr, Sakiko, and David Hulme. 2011. International Norm Dynamics and the 'End of Poverty': Understanding the Millennium Development Goals. Global Governance 17 (1): 17-36.

Haas, Peter M. 1992. Introduction: Epistemic Communities and International Policy Coordination. International Organization 46 (1): 1-35.

Haq, Mahbub ul. 1995. Reflections on Human Development. New York: Oxford University Press.

Hernandez, Carolina G., and Herman Joseph S. Kraft, eds. 2012. Mainstreaming Human Security in ASEAN Integration (three volumes). Quezon City: Institute for Strategic and Development Studies.

Hobbes, Thomas. 1996. Leviathan. Oxford: Oxford University Press.

Howe, Brendan. 2013. The Protection and Promotion of Human Security in East Asia. Basingstoke: Palgrave Macmillan.

Kant, Immanuel. 1977. Perpetual Peace: A Philosophical Sketch. In Kant's Political Writings, ed. H.S. Reiss, 93-130. Cambridge: Cambridge University Press.

Kassim, Yang Razali, ed. 2011. Strategic Currents: Issues in Human Security in Asia. Singapore: S. Rajaratnam School of International Studies and Institute of Southeast Asian Studies.

Katzenstein, Peter J. 1996. Introduction: Alternative Perspectives on National Security. In The Culture of National Security: Norms and Identity in World Politics, ed. Peter J. Katzenstein, 1-32. New York: Columbia University Press.

Kurusu, Kaoru. 2005. Development of Human Security 'Norm' and Global Governance: How is a Norm-Complex Constructed in World Politics? Kokusai Seiji (International Relations) 143: 76-91.

-2011. Japan as an Active Agent for Global Norms: The Political Dynamism Behind the Acceptance and Promotion of 'Human Security.' Asia-Pacific Review 18 (2): 115-137.

Lèvi-Strauss, Claude. 1962. La pensée sauvage. Paris: Plon.

Li, Mingjiang, ed. 2010. China and Non-Traditional Security in Asia. London: Routledge.

Martin, Mary, and Taylor Owen, eds. 2014. Routledge Handbook of Human Security. London: Routledge.

Nishikawa, Yukiko. 2010. Human Security in Southeast Asia. London: Routledge.

Ogata, Sadako. 2003. Human Security and State Security. In Human Security Now, ed. Commission on Human Security, 5. New York: Commission on Human Security.

Peou, Sorpong, ed. 2009. Human Security in East Asia: Challenges for Collaborative Action. London: Routledge.

Pitsuwan, Surin, and Mely Caballero-Anthony. 2014. Human Security in Southeast Asia: 20 Years in Review. Asian Journal of Peacebuilding 2 (2): 199-215.

Rosen, Michael. 2012. Dignity: Its History and Meaning. Cambridge, MA: Harvard University Press. 
Sandholtz, Wayne, and Kendall Stiles. 2009. International Norms and Cycles of Change. New York: Oxford University Press.

Schmitt, Carl. 1976. The Concept of the Political. Trans. George Schwab. New Brunswick: Rutgers University Press.

Sen, Amartya. 2003. Development, Rights, and Human Security. In Human Security Now, ed. The Commission on Human Security, 8-9. New York: Commission on Human Security.

- 2009. The Idea of Justice. Cambridge, MA: Belknap Press of Harvard University Press.

Tadjbakhsh, Shahrbanou, and Anuradha M. Chenoy. 2007. Human Security: Concepts and Implications. Abingdon, Oxon: Routledge.

Tanaka, Akihiko. 2015. Toward a Theory of Human Security, JICA-RI Working Paper 91. Tokyo: JICA-RI.

Teh, Benny Cheng Guan, ed. 2012. Human Security: Securing East Asia's Future. Dordrecht: Springer.

Thabchumpon, Naruemon, ed. 2012. Critical Connections: Human Rights, Human Development and Human Security. Bangkok: Chula Unisearch, Chulalongkorn University.

Tow, William T., Ramesh Thakur, and In-Taek Hyun, eds. 2000. Asia's Emerging Regional Order: Reconciling Traditional and Human Security. Tokyo: United Nations University Press.

Tow, William T., David Walton, and Rikki Kersten, eds. 2013. New Approaches to Human Security in the Asia-Pacific: China, Japan and Australia. Harnham: Ashgate.

Towns, Ann E. 2012. Norms and Social Hierarchies: Understanding International Policy Diffusion 'From Below. International Organization 66 (2): 179-209.

Umegaki, Michio, Lynn Thiesmeyer, and Atsushi Watabe, eds. 2009. Human Insecurity in East Asia. Tokyo: United Nations University Press.

UNDP (United Nations Development Programme). 1993. Human Development Report 1993. Oxford: Oxford University Press.

- 1994. Human Development Report 1994. Oxford: Oxford University Press.

UNESCO (United Nations Educational, Scientific and Cultural Organization). 2004. Proceedings of the International Conference on Human Security in East Asia. Seoul: Korean National Commission for UNESCO.

- 2007. Proceedings of the ASEAN-UNESCO Concept Workshop on Human Security in South-East Asia. Jakarta: ASEAN-UNESCO.

World Bank. 1993. The East Asian Miracle: Economic Growth and Public Policy. Oxford: Oxford University Press.

Wun'gaeo, Surichai, ed. 2004. Human Security Now: Strengthening Policy Networks in Southeast Asia. Bangkok: Center for Social Development Studies, Chulalongkorn University. 